\title{
ANALISIS PENGARUH BUDAYA ORGANISASI DAN KUALITAS KERJA TERHADAP KETERIKATAN PEGAWAI GENERASI Y
}

\author{
Amalia Destya Paramita ${ }^{1}$, Lindawati Kartika ${ }^{2}$ \\ 1,2 Institut Pertanian Bogor,amaliadestyaparamita@gmail.com \\ lindawati.kartika@gmail.com
}

\begin{abstract}
ABSTRAK
Otoritas Jasa Keuangan adalah lembaga pengawas IJK yang dibentuk berdasarkan UU No. 21 Tahun 2011 melalui pemindahan tugas pegawai BAPEPAM-LK dan BI ke OJK serta dari proses rekrutmen. Tahun 2016-2017 keterikatan pegawai mayoritas berada di level "kerja sama menyenangkan" yang dinilai berpeluang meninggalkan lembaga. Oleh sebab itu, diperlukan pemeliharaan keterikatan pegawai melalui internalisasi nilai budaya dan faktor kualitas kehidupan kerja. Tujuan penelitian menganalisis persepsi budaya organisasi, kualitas kehidupan kerja, dan keterikatan serta pengaruh dominan nilai budaya dan faktor kualitas kehidupan kerja terhadap keter-ikatan pegawai milenial. Penelitian menggunakan metode analisis deskriptif dan SEM-PLS. Persepsi pegawai mengenai budaya organisasi, kualitas kehidupan kerja, dan keterikatan mayoritas sangat baik. Hasil analisis SEM-PLS menunjukkan nilai profesionalisme dan sinergi, serta faktor penyelesaian konflik merupakan indikator dominan yang berpengaruh signifikan terhadap keterikatan pegawai pada dimensi pekerjaan dan lingkungan kerja.
\end{abstract}

Kata Kunci: Budaya organisasi, keterikatan pegawai, generasi milenial, kualitas kehidupan kerja, SEM-PLS

\begin{abstract}
The Financial Services Authority is an IJK supervisory agency established under Law Number 21 of 2011 through the employee transfer from BAPEPAM-LK and BI to OJK and from the recruitment process. In 2016-2017, the most of the employees engagement were at the level of "pleasant collaboration" which be judged to have opportunities to leave the institution. Therefore, it is necessary to keep up employee engagement through internalisation of cultural values and quality factors of work life. The purposes of the study were to analyze perceptions of organizational culture, quality of work life, and employee engagement and to analyze the dominant influence of cultural values and quality of work life factors on the engagement of millennial employees. This research was using descriptive analysis and SEM-PLS method. Employee perceptions of organizational culture, quality of work life, and employee engagement majority are very good. The results of SEM-PLS analysis show that professionalism and synergy value, and conflict resolution factors are dominant indicators that have significant effect on employee engagement to the dimensions of work and work environment.
\end{abstract}

Keywords: organizational culture, quality of work life, employee engagement, millenial generation, SEM-PLS

Naskah diterima : 15-05-2020, Naskah dipublikasikan : 30-09-2020 
PENDAHULUAN

Otoritas Jasa Keuangan (OJK) merupakan lembaga yang dibentuk berdasarkanUndang-undang Nomor 21 Tahun 2011 untuk menyelenggarakan sistem pengaturan dan pengawasan terintegrasi pada kegiatan sektor jasa keuangan. Pemenuhan kuantitas sumber daya manusia (SDM) Kantor Pusat OJK Jakarta diperoleh melalui proses peleburan dan rekrutmen yang disajikan pada Gambar 1.

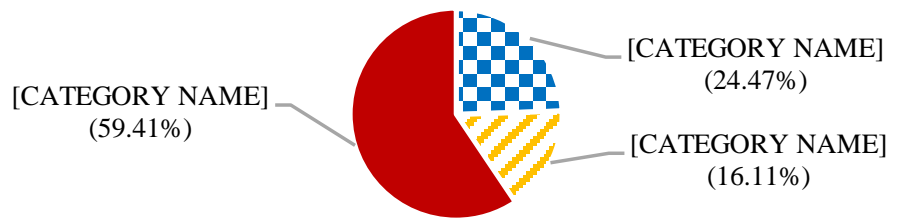

Gambar 1.Pemenuhan kuantitas sumber daya manusia Kantor Pusat Otoritas Jasa Keuangan tahun 2017

: Rekrutmen calon pegawai OJK

Berdasarkan Gambar 1 proses peleburan dilakukan melalui pemindahan tugas pegawai Badan Pengawas Pasar Modal dan Lembaga Keuangan (BAPEPAM-LK) sebanyak 24.47\% serta dari Bank Indonesia (BI) $16.11 \%$. Fokus peleburan pegawai dari BAPEPAM-LK yaitu pengaturan dan pengawasan pada sektor pasar modal dan industri keuangan non-bank (IKNB) tahun 2013 kemudian BI fokus pada sektor perbankan tahun 2014. Selanjut-nya hingga tahun 2017, pengawasan berkembang pada lembaga keuangan mikro (LKM), sehingga kebutuhan penambahan SDM diperoleh dari proses rekrutmen melalui penerimaan umum dan khusus sebanyak $59.41 \%$.

Proses pemenuhan SDM memunculkan keragaman generasi angkatan kerja di OJK. Berdasarkan usia, generasi dibedakan menjadi empat (De Meuse \& Mlodzik, 2009), tiga di antaranya disajikan pada Gambar 2.

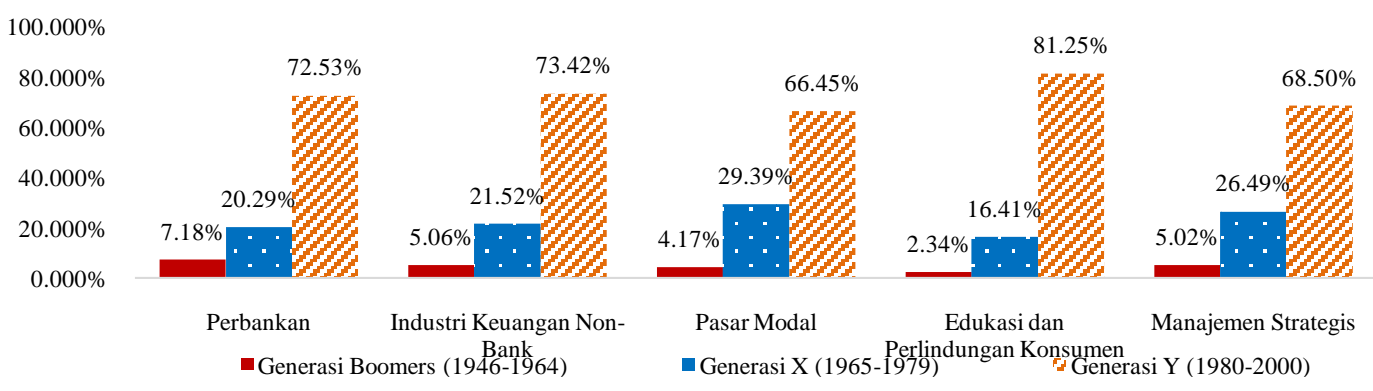

Gambar 2. Komposisi generasi angkatan kerja pada lima bidang tugas pengawasan Kantor Pusat Otoritas Jasa Keuangan Jakarta 2017

Berdasarkan Gambar 2, setiap bidang tugas pengawasan terdapat tiga generasi. Generasi Y di Kantor Pusat OJK Jakarta mendominasi 70.99\% akibat pelaksanaan periode perekrutan calon pegawai sejak 2015 hingga saat ini. Kondisi tersebut sesuai penelitian Luntungan et al., (2014), generasi Y mendominasi perusahaan $50-70 \%$. Generasi Y juga mendominasi level jabatan struktural staf sebesar $41.37 \%$. Dominasi generasi Y menyebabkan generasi tersebut menarik diteliti untuk mengetahui karakteristik generasi dalam rangka pemeliharaan SDM.

Keragaman latar belakang pegawai menimbulkan perbedaan nilai budaya, sehingga dirumuskan dan di-petakan nilai-nilai strategis untuk menyatukan SDM. Budaya yang kuat dapat menjaga dan meningkatkan citra organisasi (Mangkunegara, 2005) dan mendukung tujuan (Sutrisno, 2011). Budaya OJK diimplementasikan tahun 2014 melalui program OJK Way mencakup nilai integritas, profesionalisme, sinergi, inklusif, dan visioner yang diinternalisasikan kepadapegawai di seluruh satuan kerja untuk menciptakan kecocokan budaya individu dengan budaya organisasi yang berkembang, sehingga meningkatkan keterikatan pegawai. 
Tahun 2015, OJK melaksanakan employee opinion survey (EOS) untuk mengetahui indeks keterikatan berdasarkan tingkat kepentingan dimensi employee satisfaction index (ESI) dalam memengaruhi keterikatan pegawai. Hasil survei menunjukkan $76.79 \%$ pegawai dinyatakan engaged. Tahun 2016-2017 OJK melaksanakan EOS berdasarkan enam dimensi yang dikelompokkan menjadi lima level keterikatan pada Gambar 3.

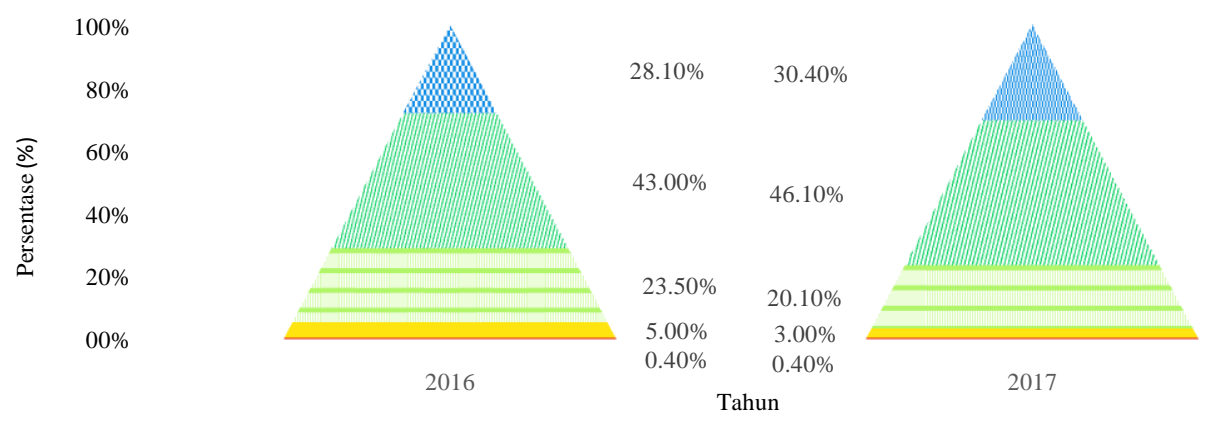

Gambar 3 Persentase engagement level pegawai OJK tahun 2016-2017

Keterangan:

aevel 1 (berontak atau berhenti) : Lev $\mathscr{C}$ (kerja sama yang menyenangkan)

: evel 2 (kepatuhan dengan kedongkolan) : Leve (komitmen sepenuh hati)

: Hevel 3 (patuh dan mau)

Berdasarkan Gambar 3, level 1 merupakan level keterikatan terendah dan level 5 yang tertinggi. Berdasar-kan kategori employee engagement survey pada salah satu badan usaha milik negara yang memiliki pegawai ter-baik dalam The Aon Best Employers Indonesia (HR in Asia 2016), persentase keterikatan pegawai OJK di level 5 ditargetkan mencapai 73.00\%. Kemajuan pencapaian keterikatan pegawai OJK pada level 1-4 sebesar $71.90 \%$ tahun 2016 dan $69.60 \%$ tahun 2017. Berdasarkan hasil survei tahun terakhir, terdapat gap sebesar $42.60 \%$ dalam mencapai target persentase keterikatan di level 5. Level keterikatan didominasi oleh pegawai level 4 yang di-anggap berpeluang meninggalkan lembaga karena kurang memperoleh hal yang diinginkan di tempat bekerja dan sisanya diisi oleh pegawai yang belum memberikan kontribusi terbaik (EOS OJK 2017). Pemeliharaan kualitas kehidupan kerja digunakan untuk menarik 42.60\% pegawai level 1-4 agar memasuki keterikatan pada level 5. Budaya organisasi dan kulitas kehidupan kerja dapat meningkatkan keterikatan agar pegawai bersedia bertahan dalam pekerjaan dan organisasi untuk mendukung visi lembaga.

Penelitian bertujuan menganalisis persepsi pegawai mengenai budaya organisasi, kualitas kehidupan kerja, dan keterikatan pegawai serta menganalisis pengaruh budaya organisasi dan kualitas kehidupan kerja terhadap keterikatan pegawai generasi Y di Kantor Pusat OJK Jakarta. Penelitian dilakukan sebagai pengembangan be-berapa penelitian terdahulu, seperti penelitian Avianti dan Kartika (2016) yang menyatakan terdapat kesesuaian persepsi generasi Y faktor kualitas kehidupan kerja dengan kompensasi sebagai faktor prioritas utama. Menurut Octaviani dan Fakhri (2016), budaya organisasi berpengaruh kuat terhadap keterikatan pegawai. Sejalan dengan hal tersebut, berdasarkan penelitian Fatimah et al.,(2015), budaya organisasi juga berpengaruh signifikan terhadap keterikatan pegawai generasi $\mathrm{Y}$. 


\section{KAJIAN LITERATUR}

Budaya Organisasi

Mangkunegara (2005) menyatakan, budaya organisasi yaitu sistem keyakinan, nilai, dan norma organisasi sebagai pedoman perilaku individu dalam mengatasi masalah. Menurut Susanto et al.,(2008), budaya organisasi dijadikan sebagai strategic tools untuk mencapai tujuan dan sebagai daya saing dalam keberhasilan organisasi.

\section{Nilai-nilai Budaya Organisasi}

Robbins dan Judge (2012) menyatakan, budaya organisasi adalah sistem makna bersama untuk membeda-kan dengan organisasi lain. Karakteristik budaya merupakan nilai dasar pemahaman anggota, mencakup inovasi dan pengambilan risiko, perhatian pada hal terperinci, orientasi hasil, orientasi individu, orientasi tim, agresivitas, dan stabilitas. Uha (2013) menyatakan, nilai organisasi adalah aturan dan pedoman perilaku untuk mengikat anggota, meliputi kebersamaan, empati, saling membantu, kedewasaan, kesediaan, organisatoris, kepedulian, ke-baikan, integritas, inovatif, kesempurnaan, fleksibilitas, dan kebijaksanaan. Otoritas Jasa Keuangan melaksanakan program OJK Way sebagai aksi perubahan perilaku dan budaya (Hadad, 2017). Transformasi budaya dilaksanakan dengan merumuskan dan memetakan nilai strategis melalui tiga perilaku utama sebagai pedoman, yaitu:

a. Integritas, ditandai dengan perilaku objektif, adil, dan konsisten.

b. Profesionalisme, ditandai perilaku tanggung jawab berdasarkan kompetensi untuk mencapai kinerja terbaik.

c. Sinergi, kolaborasi pemangku kepentingan internal dan eksternal secara produktif dan berkualitas.

d. Inklusif, sikap terbuka dan menerima keberagaman pemangku kepentingan serta memperluas kesempatan masyarakat pada industri keuangan.

e. Visioner, memiliki wawasan luas dan mampu melihat ke depan serta berpikir di luar kebiasaan.

\section{Kualitas Kehidupann Kerja (Quality of Work Life)}

Kualitas kehidupan kerja yaitu pandangan pegawai terhadap keseimbangan kehidupan pribadi berdasarkan keadaan dan praktik tujuan organisasi atau kesempatan tumbuh dan berkembang (Cascio, 2003). Faktor yang me-refleksikan kualitas kehidupan kerja mencakup partisipasi pegawai, pengembangan karir, penyelesaian konflik, komunikasi, kesehatan kerja, keselamatan kerja, keamanan kerja, kompensasi yang adil, dan kebanggaan.

\section{Keterikatan Pegawai (Employee Engagement)}

Menurut Schaufeli dan Bakker (2004), keterikatan yaitu hubungan efektif dengan aktivitas kerja, sehingga pegawai mampu manangani tuntutan pekerjaan. Menurut Maarif dan Kartika (2014), keterikatan adalah kesatuan usaha, komitmen, tanggung jawab, pikiran, tenaga, dan hati untuk mencapai kontribusi yang optimal. Keterikatan pegawai adalah hasil kombinasi dari tiga penggerak utama, dua di antaranya yaitu kepuasan dan komitmen.

\section{Aspek-aspek Keterikatan Pegawai}

Menurut Schaufeli dan Bakker (2004), keterikatanpegawai yaitu kondisi pikiran positif, memuaskan, dan berhubungan dengan pekerjaan yang ditandai tiga aspek pembentuk, mencakup vigor, dedication, dan absorption. Otoritas Jasa Keuangan melaksanakan EOS yang menghasilkan level keterikatan pegawai sebagai berikut:

a. Level 1 (berontak atau berhenti), pegawai cenderung radikal dan tidak patuh karena tidak mendapatkan hal yang dibutuhkan dalam pekerjaan, sehingga sulit dilatih dan memberikan pengaruh negatif bagi organisasi. 
b. Level 2 (kepatuhan dengan kedongkolan), pegawai kurang berkontribusi akibat perasaan kecewa karena merasa senior leader mengambil keputusan buruk dan rekan kerja tidak saling mendukung.

c. Level 3 (patuh dan mau), pegawai senang berada di organisasi tetapi belum memberikan kontribusi terbaik.

d. Level 4 (kerja sama yang menyenangkan), pegawai memberikan kontribusi baik bagi organisasi akan tetapi kurang mendapatkan hal yang diinginkan di tempat bekerja, sehingga berpeluang meninggalkan organisasi.

e. Level 5 (komitmen sepenuh hati), pegawai berkomitmen tinggi, mampu menyelaraskan kepentingan pribadi dan organisasi, serta memiliki kepuasan bekerja, sehingga mampu memberikan kontribusi penuh untuk ke-berhasilan organisasi dengan ciri menolak secara halus kepada recruiter yang menawarkan pekerjaan baru.

\section{Generasi Y (Milenial)}

Menurut De Meuse dan Mlodzik (2009), generasi berbagi pengalaman dan pandangan mengenai nilai dan sikap dan dibedakan berdasarkan tahun kelahiran, yaitu generasi tradisionals (19091945), generasi boomers (1946-1964), generasi X (1965-1979), dangenerasi Y (1980-2000). Tiga generasi yang terdapat di Kantor Pusat OJK Jakarta adalah generasi boomers, X, dan Y. Generasi Y adalah kelompok yang bertahap mendominasi angkatan kerja dan memiliki orientasi hasil kerja serta disebut generasi internet dengan karakter bergerak cepat, tidak sabar, kreatif, dan menuntut (Fatimah et al.,2015). Generasi Y tumbuh pada era teknologi (Pandey, 2017), sehingga menjadi alasan mendasar bagi organisasi untuk memahami sifat, preferensi, dan perilaku generasi $\mathrm{Y}$.

\section{Pengaruh Budaya Organisasi dan Keterikatan Pegawai}

Menurut Sutrisno (2011), budaya tercermin melalui perasaan identitas individu dan komitmen organisasi. Lockwood (2007) menyatakan, budaya organisasi adalah salah satu faktor yang berpengaruh terhadap keterikatan pegawai melalui dukungan pekerjaan, pengembangan pegawai, kondisi kerja ramah, dan saling membantu.

\section{Pengaruh Kualitas Kehidupan Kerja dan Keterikatan Pegawai}

Menurut Robbins dan Judge (2012), kualitas kehidupan kerja yaitu persepsi aspek kehidupan kerja dengan keterikatan pegawai sebagai pemicu kenyamanan lingkungan kerja. Muftah dan Lafi (2011) berpendapat, individu bergabung dan bertahan di organisasi apabila yakin terdapat kualitas kehidupan yang tinggi di tempat bekerja. Kebutuhan fisik, psikis, dan sosial yang terpenuhi berdampak positif bagi pegawai dan kelangsungan organisasi.

\section{METODE PENELITIAN}

Penelitian dilaksanakan di Kantor Pusat OJK Jakarta, 5 Februari 2018 - 20 Juli 2018 dengan mengumpul-kan data kualitatif berupa informasi program budaya dan EOS OJK serta data kuantitatif pemenuhan kuantitas SDM kantor pusat, jumlah pegawai berdasarkan demografi di seluruh level jabatan, hasil evaluasi budaya OJK 2017 dan EOS OJK 2015-2017, serta persepsi pegawai mengenai budaya OJK, kualitas kehidupan kerja, dan ke-terikatan pegawai dalam bentuk data ordinal.

Data penelitian diperoleh melalui pegawai di kantor pusat sebagai sumber primer menggunakan teknik wawancara non-sistematis dan kuesioner dengan bobot skala semi likert $1-4$. Kuesioner pertama mengenai persepsi budaya organisasi berdasarkan pedoman utama perilaku insan OJK oleh Hadad (2017). Kuesioner kedua mengenai persepsi kualitas kehidupan kerja yang diadopsi dari penelitian Kartika (2009). Kuesioner ketiga diadaptasi dari angket EOS OJK (2017) untuk mengukur keterikatan. Sedangkan sumber sekunder diperoleh dari website OJK, hasil survei, buku yang relevan, serta penelitian terdahulu berupa jurnal, skripsi, dan tesis mengenai variabel 
penelitian. Responden diambil dari populasi homogen yang tersedia sebanyak 214 pegawai pada jabatan Staf usia 23-39 tahun di Departemen Keuangan serta Departemen IKNB 1A, 1B, 2A, dan 2B karena urgensi departemen sebagai intermediator perekonomian nasional.

Penarikan sampel menggunakan teknik purposive sampling dengan kriteria masa kerja lebih dari satu tahun, convenience sampling, dan quota sampling untuk menentukan jumlah responden setiap departemen, yaitu sebanyak 12 Staf Departemen Keuangan, 21 Staf Departemen Pengawasan IKNB 1A, 25 Staf Departemen Pengawasan IKNB 1B, 21 Staf Departemen Pengawasan IKNB 2A, serta 21 Staf Departemen Pengawasan IKNB 2B. Metode pengolahan dan analisis data menggunakan uji validitas dan reliabilitas dengan software SPSS 22 (Statistical Product and Service Solution), analisis deskriptif untuk mengetahui persepsi pegawai dengan rentang skala pada Tabel 1, dan structural equation modelling (SEM)melalui pendekatan partial least square (PLS) dengan software SmartPLS 3.0.

Tabel 1. Rentang skala penilaian persepsi

\begin{tabular}{ccc}
\hline No. & Rentang skala & Keterangan \\
\hline 1. & $0 \%-25 \%$ & Sangat tidak baik \\
2. & $26 \%-50 \%$ & Kurang baik \\
3. & $51 \%-75 \%$ & Baik \\
4 & $76 \%-100 \%$ & Sangat baik \\
\hline
\end{tabular}

Berdasarkan Tabel 1, rentang skala penilaian persepsi digunakan untuk mengkategorikan hasil persepsi responden. Pernyataan dijadikan kesimpulan berdasarkan data frekuensi yang sering muncul (modus).

\section{HASIL DAN PEMBAHASAN}

\section{Karakteristik Responden}

Responden penelitian berjumlah 100 yang disajikan untuk memberikan gambara karakteristik responden berdasarkan jenis kelamin, status pernikahan, grade jabatan, dan masa kerja yang disajikan pada Tabel 2.

Tabel 2. Karakteristik responden penelitian

\begin{tabular}{|c|c|c|c|c|c|c|c|c|}
\hline \multirow{2}{*}{\multicolumn{2}{|c|}{ Karakteristik }} & \multicolumn{5}{|c|}{ Departemen } & \multirow{3}{*}{$\begin{array}{r}\text { Total } \\
31 \\
\end{array}$} & \multirow{3}{*}{$\begin{array}{l}\% \text { total } \\
31 \% \\
\end{array}$} \\
\hline & & \multirow{2}{*}{$\begin{array}{r}\text { Keuangan } \\
4 \\
\end{array}$} & \multirow{2}{*}{$\begin{array}{r}\text { IKN } \\
\text { B } 1 \mathrm{~A} \\
9\end{array}$} & \multirow{2}{*}{$\begin{array}{l}\text { IKNB } \\
\begin{array}{r}1 \mathrm{~B} \\
9\end{array}\end{array}$} & \multirow{2}{*}{$\begin{array}{l}\text { IKNB } \\
2 \mathrm{~A} \\
4 \\
4\end{array}$} & \multirow{2}{*}{$\begin{array}{r}\text { IKN } \\
\text { B 2B } \\
5 \\
\end{array}$} & & \\
\hline Jenis & Laki-laki & & & & & & & \\
\hline kelamin & Perempuan & 8 & 12 & 16 & 17 & 16 & 69 & $69 \%$ \\
\hline \multicolumn{2}{|c|}{ Subtotal } & 12 & 21 & 25 & 21 & 21 & 100 & $100 \%$ \\
\hline \multirow[b]{2}{*}{$\begin{array}{c}\text { Status } \\
\text { pernikahan }\end{array}$} & Menikah & 7 & 13 & 12 & 7 & 15 & 54 & $54 \%$ \\
\hline & $\begin{array}{c}\text { Belum } \\
\text { menikah }\end{array}$ & 5 & 8 & 13 & 14 & 6 & 46 & $46 \%$ \\
\hline \multicolumn{2}{|c|}{ Subtotal } & 12 & 21 & 25 & 21 & 21 & 100 & $100 \%$ \\
\hline \multirow{3}{*}{$\begin{array}{l}\text { Grade } \\
\text { jabatan }\end{array}$} & 4 & 5 & 0 & 2 & 4 & 0 & 11 & $11 \%$ \\
\hline & 5 & 5 & 15 & 13 & 13 & 10 & 56 & $56 \%$ \\
\hline & 6 & 2 & 6 & 10 & 4 & 11 & 33 & $33 \%$ \\
\hline \multicolumn{2}{|c|}{ Subtotal } & 12 & 21 & 25 & 21 & 21 & 100 & $100 \%$ \\
\hline \multirow{4}{*}{$\begin{array}{l}\text { Masa kerja } \\
\text { (tahun) }\end{array}$} & $1-2$ & 5 & 5 & 6 & 4 & 2 & 22 & $22 \%$ \\
\hline & $2-3$ & 2 & 3 & 6 & 7 & 6 & 24 & $24 \%$ \\
\hline & 3-4 & 5 & 11 & 13 & 9 & 11 & 49 & $49 \%$ \\
\hline & $4-5$ & 0 & 2 & 0 & 1 & 2 & 5 & $5 \%$ \\
\hline \multicolumn{2}{|c|}{ Subtotal } & 12 & 21 & 25 & 21 & 21 & 100 & $100 \%$ \\
\hline
\end{tabular}

Keterangan: Cetak tebal dominan. 
Tabel 2 menunjukkan, Staf perempuan adalah responden dominan sampel penelitian sebesar 69\% sebab data aktual jumlah pegawai perempuan di lima departemen memiliki jumlah terbanyak dibandingkan pegawai laki-laki. Karakteristik status pernikahan didominasi oleh pegawai yang sudah berstatus menikah sebanyak 54\% di-kaitkan dengan alasan untuk memenuhi kebutuhan hidup keluarga. Grading jabatan ditentukan berdasarkan PDK No. 01/15/PDK/XII/2012, bahwa pegawai level jabatan struktural Staf ditempatkan pada grade jabatan 4-6. Responden terbanyak yaitu Staf pada grade jabatan 5 sebesar 56\%. Kenaikan grade jabatan mempertimbangkan masa kerja, pendidikan, dan rekomendasi atasan.Berkaitan dengan salah satu pertimbangan tersebut responden didominasi oleh Staf dengan masa kerja 3-4 tahun sebesar 49\% sebab fungsi IKNB mulai aktif pada tahun 2013.

\section{Uji Validitas dan Reliabilitas}

Uji validitas digunakan untuk mengetahui pengukuran objek penelitian menggunakan pertanyaan tertutup dengan bobot skor 1-4. Berdasarkan hasil pengujian, seluruh item pernyataan dikatakan valid karena nilai r-hitung $>0.197$. Selanjutnya uji reliabilitas berkaitan dengan keandalan instrumen (kuesioner) penelitian yang merupakan indikator dari variabel atau konstruk dan dilakukan pada item kuesioner yang valid. Hasil uji reliabilitas kuesioner penelitian secara umum dinyatakan reliabel karena memiliki batasan nilai Cronbach Alpha lebih dari 0.600 .

\section{Analisis Deskriptif Budaya Organisasi, Kualitas Kehidupan Kerja, dan Keterikatan Pegawai}

Otoritas Jasa Keuangan memiliki lima nilai budaya yang disingkat sebagai INPRESIV sebagai pedoman perilaku pegawai. Rekapitulasi hasil analisis deskriptif pegawai mengenai budaya OJK disajikan pada Gambar 4.

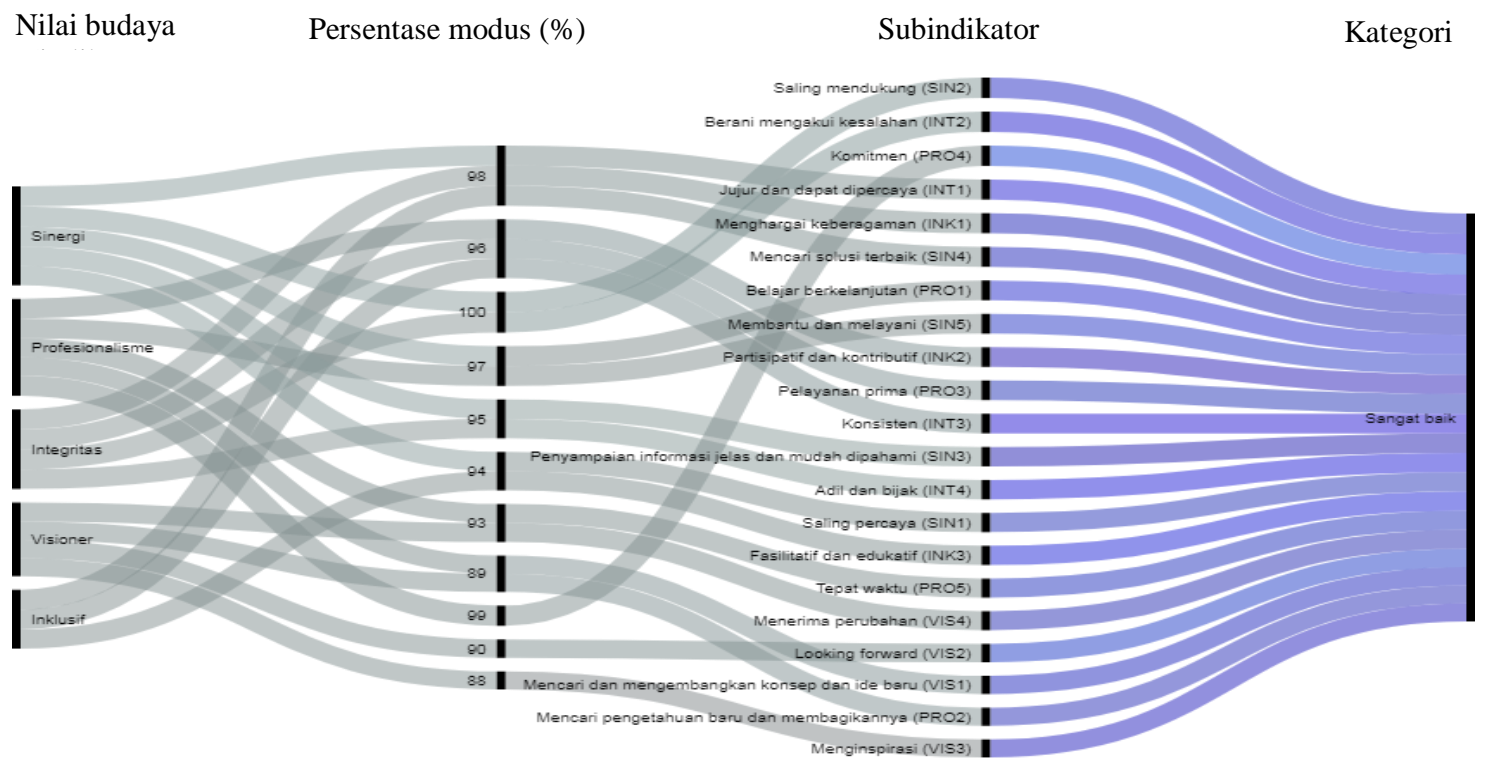

Keterangan:
: Sangat baik;

Gambar 4. Persepsi pegawai generasi Y terhadap budaya organisasi : Persentase modus 3 dan 4 tertinggi; : Persentase modus 3 dan 4 terendah.

Gambar 4 menunjukkan implementasi budaya OJK sudah sangat baik. Nilai modus dengan persentase ter-tinggi yaitu sikap berani mengakui kesalahan dan saling mendukung. Sikap berani mengakui kesalahan adalah wujud perilaku jujur pada nilai integritas sebagai perilaku mendasar yang wajib dimiliki setiap pegawai. Sikap bersedia mengakui kesalahan 
diimplementasikan melalui permintaan maaf atas kesalahan yang telah dilakukan meskipun kesalahan kecil. Sikap saling percaya adalah wujud perilaku saling mendukung pada nilai sinergi agar seluruh pegawai dapat mencapai tujuan bersama melalui penyampaian informasi positif serta kesempatan dan kepercayaan kepada rekan kerja untuk menerima pembagian tanggung jawab secara seimbang. Nilai modus dengan persentase terendah adalah perilaku mengispirasi sebagai bentuk dukungan perubahan pada nilai visioner. Pegawai mendedikasikan diri sebagai penggerak perubahan lingkungan kerja yang dimulai melalui tindakan kecil dan sikap optimis dalam menyikapi perubahan, sehingga menjadi inspirator perubahan bagi sesama rekan kerja.Kualitas kehidupan kerja direfleksikan oleh sembilan faktor. Rekapitulasi hasil analisis deskriptif pegawai mengenai kualitas kehidupan kerja disajikan pada Gambar 5.

$\begin{array}{cccc}\text { Faktor (indikator) } & \text { Persentase modus } & \text { Subfaktor } & \text { Kategori }\end{array}$

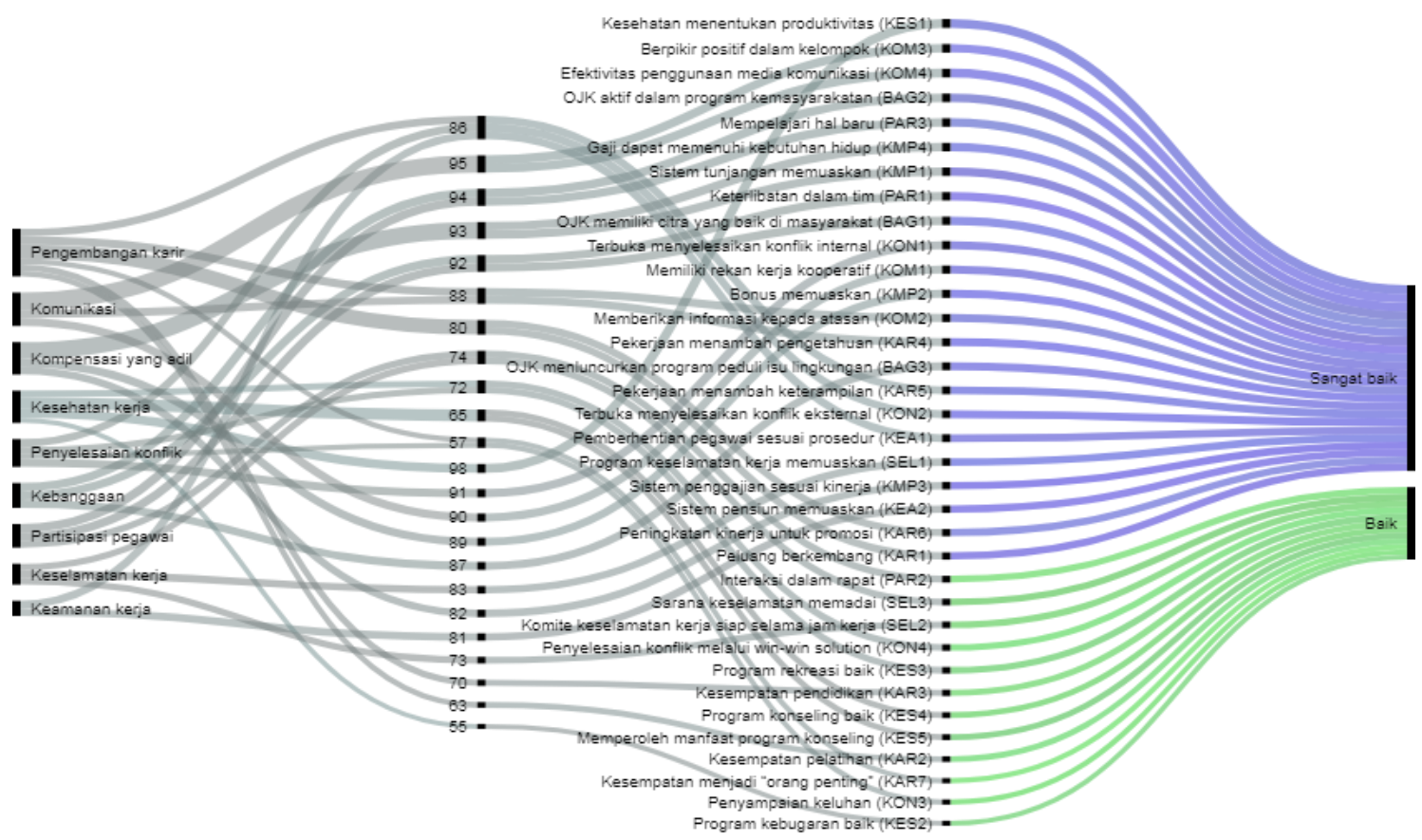

Gambar 5. Persepsi pegawai generasi Y terhadap kualitas kehidupan kerja

Keterangan:

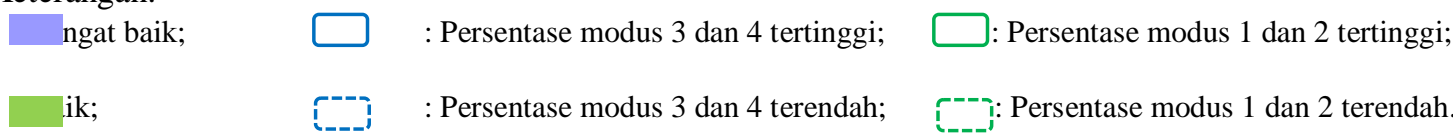

Gambar 5 memperlihatkan penilaian pegawai terhadap kualitas kehidupan kerja yang dinilai baik hingga sangat baik. Persentase nilai modus 3 dan 4 tertinggi pada subfaktor kesehatan sebagai penentu produktivitas dalam menghasilkan pekerjaan berkualitas. Kondisi tersebut didukung dengan tersedianya fasilitas pemeriksaan kesehatan di setiap satuan kerja untuk menghindari penurunan produktivitas kerja. Nilai modus 3 dan 4 dengan persentase terendah yaitu kesempatan menjadi "orang penting" dan proses penyampaian keluhan. Setiap individu memiliki peran penting sesuai ruang lingkup dan tanggung jawab pekerjaan. Kesempatan diperoleh berdasarkan penilaian kinerja individu secara adil dan akurat. Proses penyampaian keluhan dilaksanakan melalui kegiatan diskusi untuk menyelesaikan permasalahan perbedaan pendapat, yaitu melalui kegiatan rapat. Pengambilan ke-putusan tidak hanya diputuskan oleh pemimpin, akan tetapi mempertimbangkan pendapat setiap pegawai untuk menetapkan kebijakan baru di lingkungan kerja. Nilai modus 1 dan 2 dengan persentase tertinggi pada 
program rekreasi yang merupakan salah satu kegiatan untuk menumbuhkan persaudaraan antarpegawai serta meningkatkan jalinan komunikasi antara pegawai dan pimpinan melalui kegiatan refreshment. Program dapat berupa pengambil-an cuti dengan maksud menghindari kejenuhan rutinitas monoton di tempat bekerja atau kegiatan outing kantor. Nilai modus 1 dan 2 dengan persentase terendah yaitu program kebugaran yang bertujuan meningkatkan perilaku hidup sehat di tempat bekerja berupa olahraga setiap Jumat pagi di Monumen Nasional Jakarta dan senam bersama setiap bulan. Namun, akibat keterbatasan sarana gedung perkantoran yang dipindahkan awal tahun 2018, pegawai kesulitan mengikuti program rutin di tempat sebelumnya. Oleh sebab itu, pegawai bergabung ke dalam komunitas olahraga untuk menjaga kebugaran tubuh.Keterikatan pegawai OJK direfleksikan oleh enam dimensi. Rekapitulasi hasil analisis deskriptif mengenai keterikatan pegawai generasi Y di Kantor Pusat OJK Jakarta disajikan pada Gambar 6.

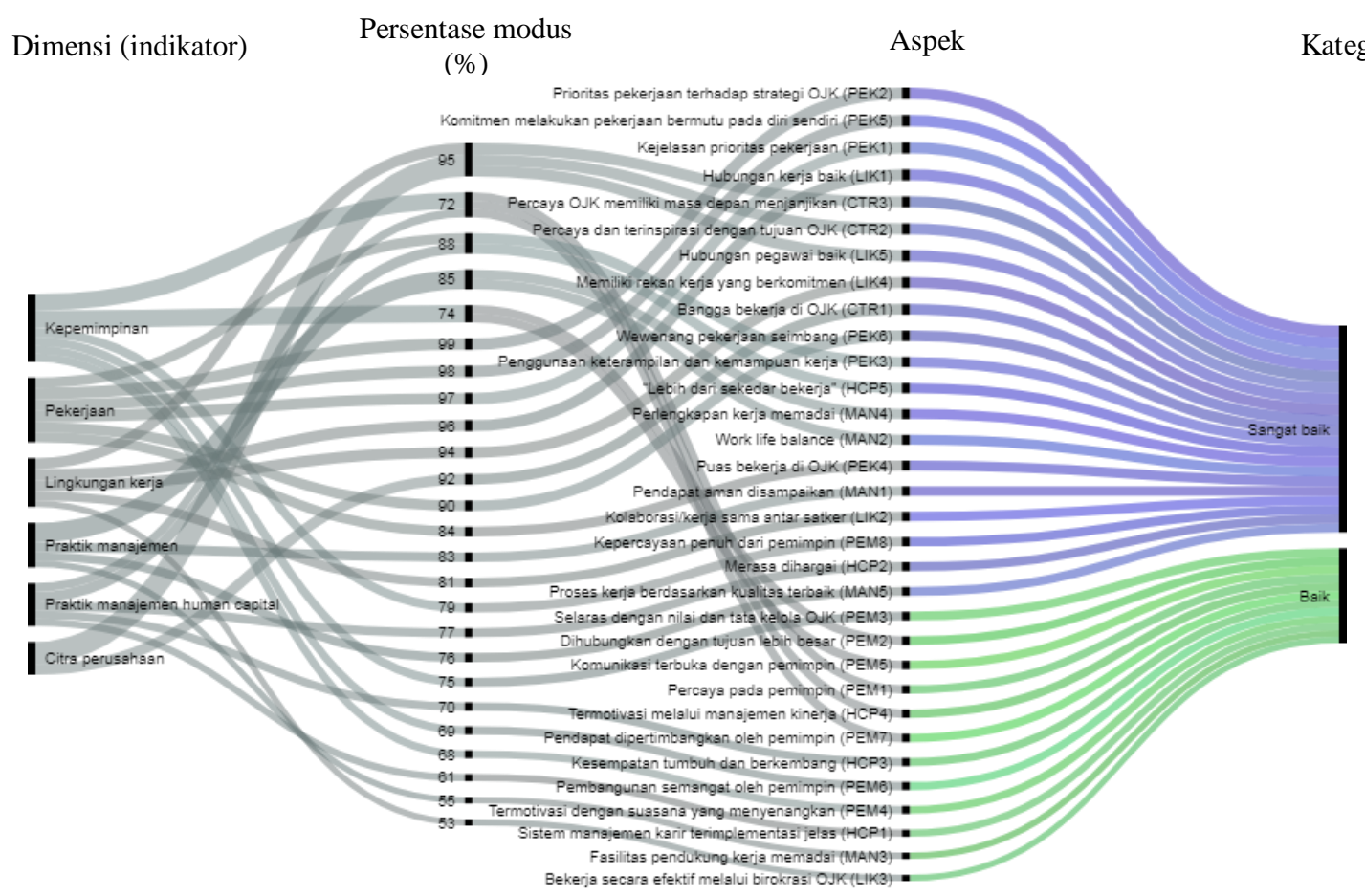

Gambar 6. Persepsi pegawai generasi Y terhadap keterikatan pegawai

Keterangan:

$\begin{array}{rll}\text { : Sangat baik } & \text { : Persentase modus } 3 \text { dan } 4 \text { tertinggi } \\ \text { aik } & \text { : Persentase modus } 3 \text { dan } 4 \text { terendah }\end{array}$

Berdasarkan Gambar 6 persepsi keterikatan pegawai generasi Y di Kantor Pusat OJK Jakarta secara umum dikategorikan baik hingga sangat baik. Persentase modus tertinggi yaitu aspek tantangan pada dimensi pekerja-an. Pegawai memiliki tantangan pekerjaan karena dituntut memahami prioritas pekerjaan yang dimiliki dalam rangka mendukung strategi OJK yang lebih besar. Tahun 2018 dihasilkan kebijakan dalam menjaga stabilitas sistem keuangan dan peran sektor jasa keuangan guna memacu pertumbuhan ekonomi yang banyak berhubungan dengan pihak eksternal, sehingga pegawai dituntut mampu beradaptasi dengan kemungkinan perubahan tantang-an. Persentase nilai modus terendah yaitu aspek kepedulian (respect) pegawai pada dimensi lingkungan kerja. Otoritas Jasa Keuangan merupakan lembaga regulator yang memiliki birokrasi dalam setiap pekerjaan. Namun pegawai tidak merasa terhambat dengan birokrasi kerja yang ditetapkan dan diterapkan karena dinilai sebagai aturan yang dapat membantu efektivitas kerja dalam melayani pihak internal maupun eksternal. 


\section{Analisis Pengaruh Budaya Organisasi dan Kualitas Kehidupan Kerja terhadap Keterikatan Pegawai \\ Model penelitian yang diujikan terdiri dari dua model untuk menemukan pilihan model terbaik berdasarkan kriteria penilaian PLS. Hasil evaluasi outer dan inner model pada model I dan II disajikan pada Tabel 3.}

Tabel 3. Hasil evaluasi outer model dan inner model pada model I dan II

\begin{tabular}{|c|c|c|c|c|c|}
\hline No. & $\begin{array}{l}\text { Kriteria } \\
\text { evaluasi }\end{array}$ & Syarat & Model I & Model II & $\begin{array}{l}\text { Model } \\
\text { terpilih }\end{array}$ \\
\hline \multicolumn{6}{|c|}{ Evaluasi model pengukuran (outer model) } \\
\hline 1. & $\begin{array}{l}\text { Loading } \\
\text { factor }\end{array}$ & $>0.700$ & $\begin{array}{l}\text { Reduksi } 5 \text { manifest } \\
<0.700 \\
\text { (Valid) }\end{array}$ & $\begin{array}{l}\text { Reduksi } 8 \text { manifest }<0.700 \\
\text { (Valid) }\end{array}$ & \multirow{4}{*}{$\frac{-1}{\overline{0}}$} \\
\hline 2. & $\begin{array}{l}\text { Average } \\
\text { Variance } \\
\text { Extracted } \\
\text { (AVE) }\end{array}$ & $>0.500$ & $\begin{array}{l}\text { BO: } 0.775 \\
\text { KK: } 0.599 \\
\text { KP: } 0.664 \\
\text { (Valid) }\end{array}$ & $\begin{array}{l}\text { INK: 0.764, INT: 0.760, PRO: 0.691, } \\
\text { SIN: 0.666, VIS: 0.664;PAR: 0.742, } \\
\text { KAR: 0.665, } \\
\text { KON: 0.598, KOM: 0.698, KES: } \\
0.838, \\
\text { KEA: } 0.710, \text { SEL: } 0.916, \text { KMP: } 0.795 \text {, } \\
\text { BAG: } 0.777 ; \text { KP: } 0.664 \\
\text { (Valid) }\end{array}$ & \\
\hline 3. & $\begin{array}{l}\text { Cross } \\
\text { loading }\end{array}$ & $\begin{array}{l}>\text { indikator } \\
\text { variabel laten } \\
\text { lainnya }\end{array}$ & $\begin{array}{l}\text { Semua loading blok } \\
\text { indikator > } \\
\text { indikator variabel } \\
\text { laten lain } \\
\text { (Valid) }\end{array}$ & $\begin{array}{l}\text { Semua loading blok indikator > } \\
\text { indikator variabel laten lain } \\
\text { (Valid) }\end{array}$ & \\
\hline 4. & $\begin{array}{l}\text { Composite } \\
\text { reliability }\end{array}$ & $>0.600$ & $\begin{array}{l}\text { BO: } 0.945 \\
\text { KK: } 0.882 \\
\text { KP: } 0.908 \\
\text { (Reliabel) }\end{array}$ & $\begin{array}{l}\text { INK: } 0.906, \text { INT: } 0.905, \text { PRO: } 0.899 \text {, } \\
\text { SIN: 0.909, VIS: 0.887; PAR: 0.851, } \\
\text { KAR: } 0.909 \text {, } \\
\text { KON: } 0.856, \text { KOM: } 0.874, \text { KES: } \\
0.954, \\
\text { KEA: } 0.829 \text {, SEL: } 0.970, \text { KMP: 0.939, } \\
\text { BAG: } 0.913 ; \text { KP: } 0.908 \\
\text { (Reliabel) }\end{array}$ & \\
\hline \multicolumn{6}{|c|}{ Evaluasi model struktural (inner model) } \\
\hline 1. & $\begin{array}{l}\text { Estimasi } \\
\text { koefisien } \\
\text { jalur }\end{array}$ & $\begin{array}{l}\text { Nilai estimasi } \\
\text { hubungan jalur } \\
\text { model harus } \\
\text { signifikan yang } \\
\text { diperoleh } \\
\text { dengan prosedur } \\
\text { bootstrapping. } \\
\text { Nilai t-statistik } \\
\text { lebih dari } 1.96 \\
(5 \%)\end{array}$ & $\begin{array}{l}\mathrm{BO} \rightarrow \mathrm{KP}: 2.698 \\
\mathrm{KK} \rightarrow \mathrm{KP}: 8.600 \\
\text { (berpengaruh) }\end{array}$ & $\begin{array}{l}\mathrm{INT} \rightarrow \mathrm{KP}: 2.473, \mathrm{KAR} \rightarrow \mathrm{KP}: 3.742, \\
\mathrm{KOM} \rightarrow \mathrm{KP}: 2.384 \\
(\text { berpengaruh) } \\
\mathrm{PRO} \rightarrow \mathrm{KP}: 0.890, \mathrm{SIN} \rightarrow \mathrm{KP}: 1.094, \\
\mathrm{INK} \rightarrow \mathrm{KP}: 1.861, \mathrm{VIS} \rightarrow \mathrm{KP}: 1.588, \\
\mathrm{PAR} \rightarrow \mathrm{KP}: 1.061, \mathrm{KON} \rightarrow \mathrm{KP}: 0.855, \\
\mathrm{KES} \rightarrow \mathrm{KP}: 0.501, \mathrm{KEA} \rightarrow \mathrm{KP}: 0.103, \\
\mathrm{SEL} \rightarrow \mathrm{KP}: 0.370, \mathrm{KMP} \rightarrow \mathrm{KP}: 1.659, \\
\mathrm{BAG} \rightarrow \mathrm{KP}: 0.804 \\
(\text { tidak berpengaruh) }\end{array}$ & \multirow[t]{2}{*}{$\frac{1}{\overline{0}}$} \\
\hline 2. & $\begin{array}{l}\mathrm{R} \text { square } \\
\text { adjusted }\end{array}$ & $\begin{array}{l}\text { Baik }(0.670), \\
\text { moderat }(0.330), \\
\text { dan lemah } \\
(0.190)\end{array}$ & $\begin{array}{l}0.699 \\
\text { (baik) }\end{array}$ & $\begin{array}{l}0.685 \\
\text { (baik) }\end{array}$ & \\
\hline
\end{tabular}

Tabel 3 menghasilkan model I sebagai model terbaik yang kemudian dianalisis lebih lanjut. Evaluasi model pengukuran menghasilkan model akhir penelitian yang divisualisasikan pada Gambar 7. 


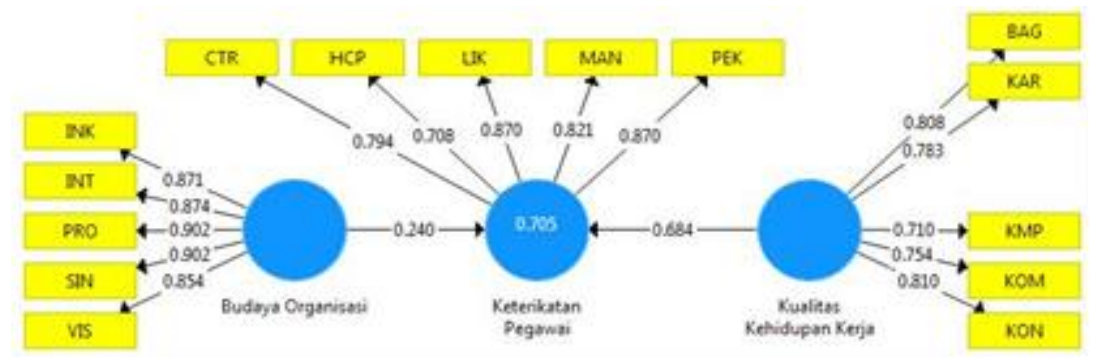

Gambar 7. Model akhir pengaruh budaya organisasi dan kualitas kehidupan kerja terhadap keterikatan pegawai generasi $Y$

Keterangan: $\square$ : indikator dengan nilai loading factor terbesar.

$\begin{array}{llllll}\text { INT } & \text { : Integritas } & \text { KAR } & \text { :Pengembangan karir } & \text { HCP } & \begin{array}{l}\text { :Praktik manajemen } \\ \text { capital }\end{array} \\ & & & & & \text { human } \\ \text { PRO } & \text { : Profesionalisme } & \text { KON } & \text { :Penyelesaian konflik } & \text { PEK } & \text { : Pekerjaan } \\ \text { SIN } & : \text { Sinergi } & \text { KOM } & : \text { Komunikasi } & \text { LIK } & \text { : Lingkungan kerja } \\ \text { INK } & : \text { Inklusif } & \text { KMP } & \text { :Kompensasi yang adil } & \text { MAN } & \text { : Praktik manajemen } \\ \text { VIS } & : \text { Visioner } & \text { BAG } & : \text { Kebanggaan } & \text { CTR } & \text { : Citra perusahaan }\end{array}$

Berdasarkan Gambar 9, lima indikator yang direduksi karena nilai loading factor kurang dari 0.700, yaitu keamanan kerja (KEA), kepemimpinan (PEM), keselamatan kerja (SEL), partisipasi pegawai (PAR), kesehatan kerja (KES). Lima belas indikator yang lain telah memenuhi syarat loading factor, sehingga validitas model baik. Model akhir menunjukkan indikator budaya organisasi dominan pada nilai profesionalisme dan sinergi sebesar 0.902. Hal tersebut menunjukkan Staf Kantor Pusat OJK Jakarta senantiasa belajar berkelanjutan, memberikan pelayanan prima, dan berkomitmen pada hasil kerja berkualitas. Komitmen hasil kerja sesuai dengan penelitian Luntungan et al., (2014) bahwa generasi Y berorientasi pada hasil. Nilai loading factor tertinggi pada variabel kualitas kehidupan kerja yaitu faktor penyelesaian konflik sebesar 0.810. Kondisi tersebut menunjukkan, pegawai menginginkan suasana terbuka untuk menyelesaikan konflik dengan menemukan win-win solution. Pegawai juga mementingkan proses penyampaian keluhan dengan harapan dilakukan prioritas identifikasi dan penyelesaian. Kondisi tersebut sesuai dengan pendapat Mukundan et al.,(2013) yang menyatakan bahwa generasi $\mathrm{Y}$ lebih senang melakukan negosiasi melalui gambaran penyelesaian permasalahan. Sedangkan nilai loading factor tertinggi pada variabel keterikatan pegawai yaitu dimensi pekerjaan dan lingkungan kerja sebesar 0.870. Kondisi tersebut menunjukkan, pegawai memiliki pemahaman jelas terhadap pekerjaan dan prioritas tantangan pekerjaan. Pegawai mencari peluang untuk dapat menggunakan seluruh keterampilan dan kemampuan yang sesuai dengan pernyataan Murphy (2007) bahwa generasi Y memiliki antusias untuk berkembang melalui berbagai kesempatan yang ada. Selanjutnya, evaluasi discriminant validity dilakukan dengan melihat nilai cross loading pada Tabel 4. 
Tabel 4. Nilai cross loading pengujian outer model pada model I

\begin{tabular}{lccc}
\hline \multicolumn{1}{c}{ Variabel laten } & $\begin{array}{c}\text { Budaya } \\
\text { organisasi }\end{array}$ & $\begin{array}{c}\text { Kualitas kehidupan } \\
\text { kerja }\end{array}$ & $\begin{array}{c}\text { Keterikatan } \\
\text { pegawai }\end{array}$ \\
\hline Integritas (INT) & $\mathbf{0 . 8 7 6}$ & 0.460 & 0.554 \\
Profesionalisme (PRO) & $\mathbf{0 . 9 0 2}$ & 0.552 & 0.622 \\
Sinergi (SIN) & $\mathbf{0 . 9 0 2}$ & 0.394 & 0.469 \\
Inklusif (INK) & $\mathbf{0 . 8 7 2}$ & 0.488 & 0.478 \\
Visioner (VIS) & $\mathbf{0 . 8 5 4}$ & 0.490 & 0.551 \\
Pengembangan karir (KAR) & 0.303 & $\mathbf{0 . 7 8 3}$ & 0.677 \\
Penyelesaian konflik (KON) & 0.434 & $\mathbf{0 . 8 1 0}$ & 0.638 \\
Komunikasi (KOM) & 0.604 & $\mathbf{0 . 7 5 4}$ & 0.633 \\
Kompensasi yang adil (KMP) & 0.317 & $\mathbf{0 . 7 1 0}$ & 0.559 \\
Kebanggaan (BAG) & 0.452 & $\mathbf{0 . 8 0 8}$ & 0.638 \\
\hline Praktik manajemen human capital & 0.307 & 0.653 & $\mathbf{0 . 7 0 9}$ \\
(HCP) & & & \\
Pekerjaan (PEK) & 0.627 & 0.657 & $\mathbf{0 . 8 7 0}$ \\
Lingkungan kerja (LIK) & 0.678 & 0.687 & $\mathbf{0 . 8 7 0}$ \\
Praktik manajemen (MAN) & 0.348 & 0.683 & $\mathbf{0 . 8 2 1}$ \\
Citra perusahaan (CTR) & 0.494 & 0.644 & $\mathbf{0 . 7 9 4}$ \\
\hline
\end{tabular}

Berdasarkan Tabel 4, setiap indikator yang mengukur konstruk memiliki korelasi lebih besar dibandingkan konstruk lain, sehingga model I memiliki discriminant validity baik. Selanjutnya, penilaian validitas melalui nilai AVE dan reliabilitas konstrak dilihat dari output konstrak validitas dan reliabilitas pada Tabel 5 .

Tabel 5. Output konstrak validitas dan reliabilitas

\begin{tabular}{lccc}
\hline & Average Variance Extracted & Composite reliability & Cronbach's Alpha \\
\hline Budaya organisasi & 0.775 & 0.945 & 0.928 \\
Kualitas kehidupan kerja & 0.599 & 0.882 & 0.832 \\
Keterikatan pegawai & 0.664 & 0.908 & 0.872 \\
\hline
\end{tabular}

Tabel 5 menunjukkan nilai AVE setiap konstruk di atas 0.500, sehingga model baik. Composite reliability dan cronbach's alpha bernilai lebih dari 0.600, sehingga konstruk model memiliki konsistensi internal baik.

Evaluasi model struktural melihat nilai R-square adjusted model akhir sebesar 0.699 yang menjelaskan variabel konstruk keterikatan pegawai dapat dijelaskan oleh variabel budaya organisasi dan kualitas kehidupan kerja sebesar $69.90 \%$ dan $30.10 \%$ dijelaskan oleh variabel lain di luar model. Model pengukuran yang telah sesuai dan merefleksikan variabel laten dilakukan bootstrapping untuk menghasilkan model struktural dengan melihat hubungan konstruk melalui estimasi koefisien parameter jalur dan tingkat signifikansipada Gambar 10.

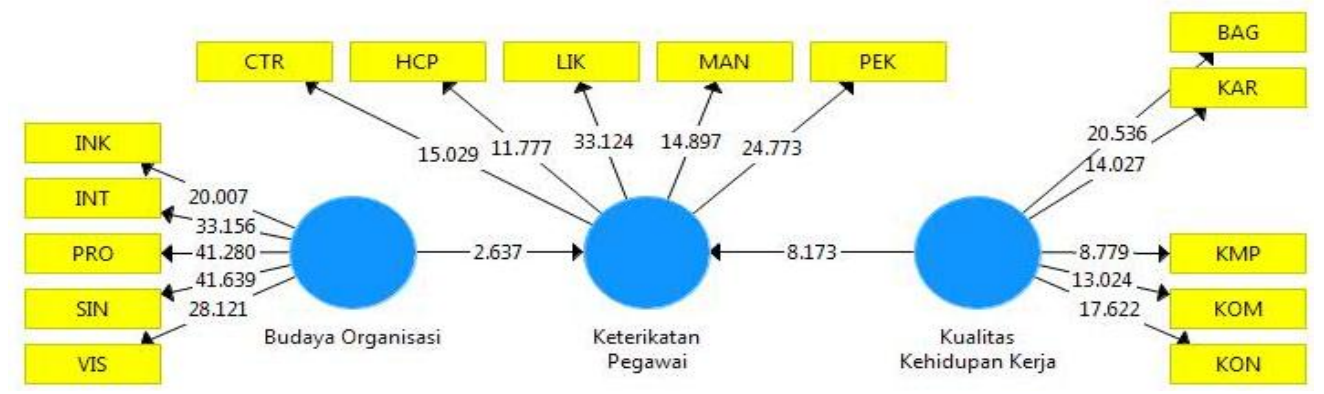


Gambar 8. Model bootstrapping pengaruh budaya organisasi dan kualitas kehidupan kerja terhadap keterikatan pegawai generasi Y

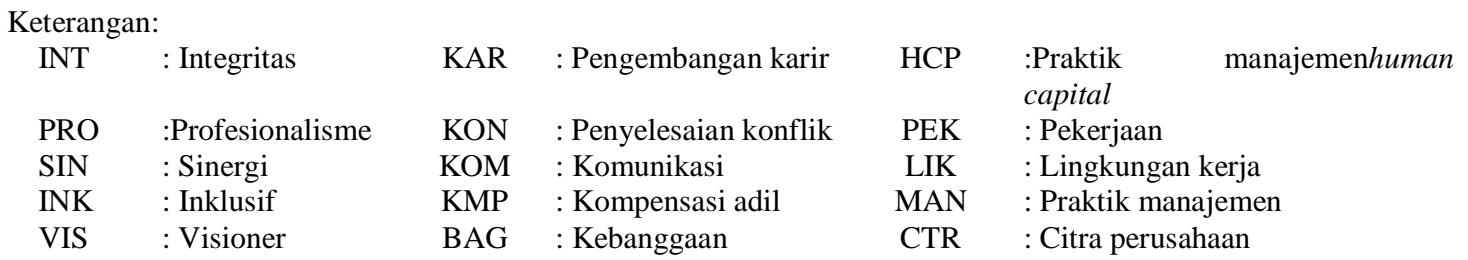

Berdasarkan Gambar 8, t-statistic setiap indikator lebih dari 1.960, sehingga memiliki validitas signifikan. Langkah bootstrapping menghasilkan outputpath coefficient untuk menilai signifikansi statistik model melalui pengujian hipotesis setiap jalur hubungan yang disajikan pada Tabel 6.

Tabel 6. Output path coefficient model I

\begin{tabular}{lccccc}
\hline & $\begin{array}{c}\text { Original } \\
\text { sample }(\mathbf{O})\end{array}$ & $\begin{array}{c}\text { Standard } \\
\text { Deviation } \\
(\text { STDEV) }\end{array}$ & $\begin{array}{c}\text { T-statistic } \\
(\mid \mathbf{O} / \text { STDEV })\end{array}$ & $\begin{array}{c}\text { P- } \\
\text { values }\end{array}$ & $\begin{array}{c}\text { Evaluasi } \\
\text { model }\end{array}$ \\
\hline $\begin{array}{l}\text { Budaya Organisasi } \rightarrow \text { Keterikatan } \\
\text { Pegawai }\end{array}$ & 0.240 & 0.091 & 2.766 & 0.009 & Signifikan \\
$\begin{array}{l}\text { Kualitas Kehidupan Kerja } \rightarrow \\
\text { Keterikatan Pegawai }\end{array}$ & 0.684 & 0.084 & 8.709 & 0.000 & Signifikan \\
\hline
\end{tabular}

Tabel 6 memperlihatkan hubungan positif variabel penelitian. Budaya organisasi yang secara konsisten di-implementasikan mampu memperkuat keterikatan pegawai dengan kontribusi sebesar 0.240. Kualitas kehidupan kerja melalui kesempatan tumbuh dan berkembang dapat meningkatkan keterikatan dengan kontribusi terbesar yaitu 0.684. Berdasarkan hasil uji hipotesis, terbukti budaya organisasi $\left(\mathrm{H}_{1 \mathrm{a}}\right)$ dan kulitas kehidupan kerja $\left(\mathrm{H}_{1 \mathrm{~b}}\right)$ berpengaruh signifikan terhadap keterikatan pegawai generasi Y. Hasil analisis sesuai penelitian Akbar (2013) bahwa budaya organisasi berpengaruh signifikan terhadap keterikatan pegawai, sehingga semakin baik budaya organisasi maka semakin tinggi keterikatan dan sebaliknya. Dominasi nilai profesionalisme dalam memengaruhi keterikatan menunjukkan, pegawai berkomitmen pada hasil kerja berkualitas yang sesuai dengan penelitian Fatimah et al., (2015) bahwa budaya organisasi pada orientasi hasil pekerjaan di kalangan generasi $\mathrm{Y}$ berpengaruh signifikan terhadap keterikatan. Hasil penelitian pengaruh kualitas kehidupan kerja terhadap keterikatan pegawai didukung penelitian Tahir (2015) bahwa kualitas kehidupan kerja berpengaruh positif terhadap keterikatan.

Berdasarkan hasil penelitian dirumuskan konsep implikasi manajerial berupa model desain pemeliharaan keterikatan pegawai yang dimodifikasi dari diagram pohon untuk mengembangkan langkah pencapaian hasil spesifik (Duffy et al.,2012). Model desain pemeliharaan diilustrasikan pada Gambar 9 di bawah ini. Berdasarkan Gambar 9, upaya pemeliharaan keterikatan pegawai generasi $\mathrm{Y}$ direkomendasikan melalui dua prioritas pengembangan program yaitu program prioritas pertama dan program prioritas kedua. Prioritas pertama pada bagian pemicu keterikatan pegawai yaitu nilai budaya profesionalisme dan sinergi. Perilaku utama nilai profesionalisme yang dapat ditingkatkan yaitu perilaku pencarian dan berbagi pengetahuan baru dalam kegiatan belajar berkelanjutan untuk menjaga kredibilitas lembaga (Pandey, 2017). Sedangkan Prioritas kedua yaitu nilai integritas dan faktor kebanggaan. Perilaku nilai integritas yang dapat ditingkat-kan yaitu sikap adil dan bijak yang ditandai dengan pemberian kesempatan kepada rekan kerja untuk menyampai-kan pendapat dan mengembangkan diri dalam setiap pertemuan rutin (rapat).Hingga saat ini, OJK telah melaksanakan beberapa program peduli lingkungan di kalangan masyarakat. Berkaitan dengan 


\section{JURNAL EKOBIS: EKONOMI, BISNIS \& MANAJEMEN Vol X Nomor X (year)}

program eksternal tersebut, OJK sebaiknya menguatkan internal lembaga terhadap isu lingkungan melalui internal greening of management dengan fokus pada proses kerja yang ramah lingkungan, seperti efisiensi penggunaan energi yang dimiliki di gedung perkantoran selama jam operasional kerja.

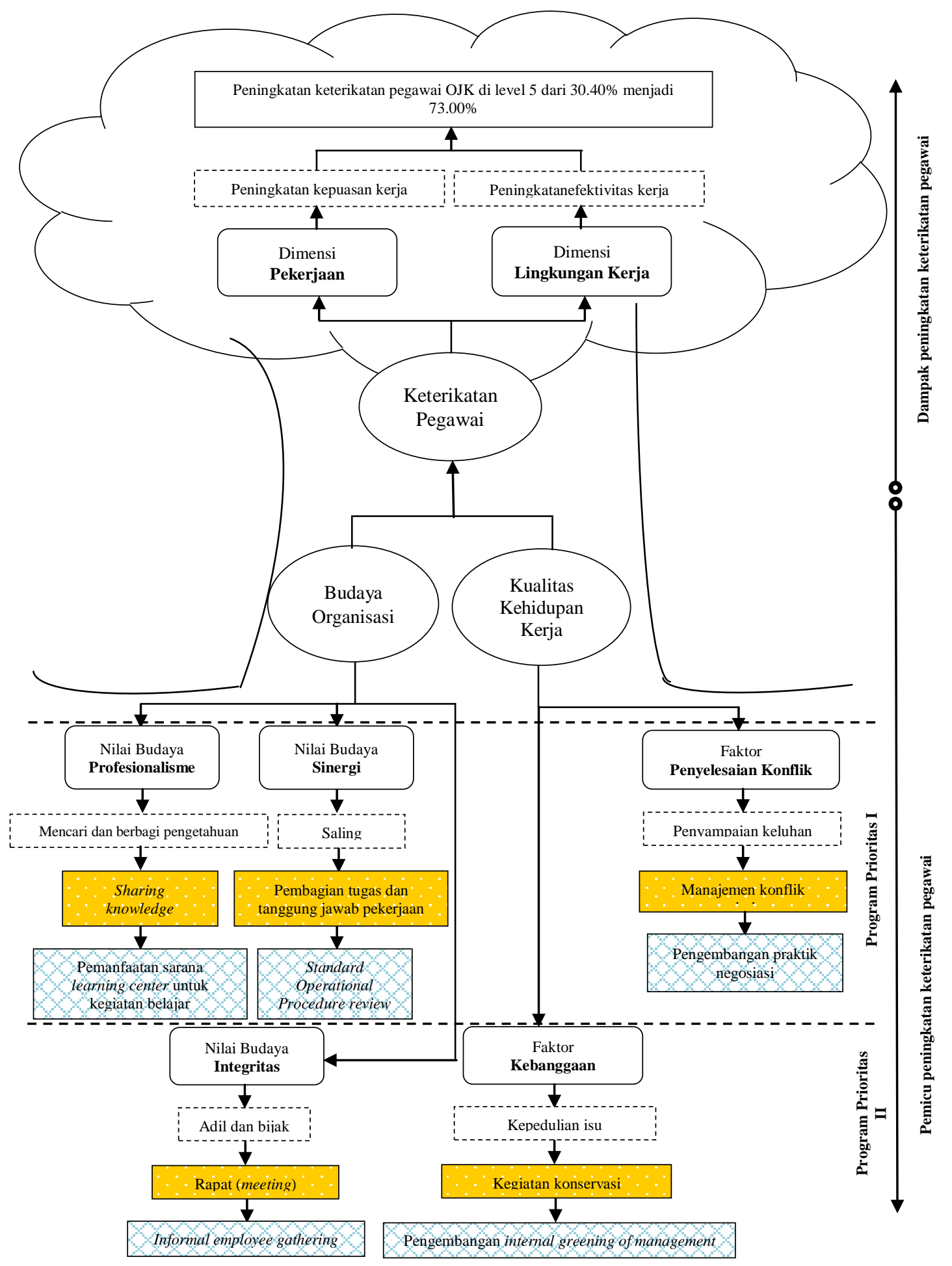

Gambar 9.Model desain pemeliharaan keterikatan pegawai generasi Y di Kantor Pusat OJK Jakarta

Keterangan: 


\author{
: variabel penelitian \\ : nilai/faktor dominan \\ : perilaku/aspek yang sebaiknya ditingkatkan
}

: program/kegiatan prioritas

: rekomendasi pengembangan

\section{PENUTUP}

\section{Simpulan}

Hasil penelitian mengenai analisis pengaruh budaya organisasi dan kualitas kehidupan kerja terhadap ke-terikatan pegawai pada generasi Y di Kantor Pusat OJK Jakarta dapat disimpulkan bahwa Persepsi pegawai terhadap nilai budaya integritas, profesionalisme, sinergi, inklusif, dan visioner dikategori-kan sangat baik. Persepsi tertinggi yaitu pada nilai integritas dan sinergi. Kualitas kehidupan kerja pada faktor partisipasi pegawai, pengembangan karir, penyelesaian konflik, komunikasi, kesehatan, keamanan, dan ke-selamatan kerja, kompensasi yang adil, serta kebanggaan mayoritas sangat baik. Persepsi tertinggi pada faktor kesehatan kerja. Keterikatan pegawai mengenai dimensi praktik manajemen human capital, kepemimpinan, pekerjaan, lingkungan kerja, praktik manajemen, dan citra perusahaan mayoritas sangat baik. Persepsi ter-tinggi pada dimensi pekerjaan.Pengaruh budaya organisasi dan kualitas kehidupan kerja terhadap keterikatan pegawai generasi Y di Kantor Pusat OJK Jakarta berpengaruh signifikan dengan indikator tertinggi pada nilai budaya profesionalisme dan sinergi karena pegawai berorientasi terhadap hasil. Indikator kualitas kehidupan kerja tertinggi pada faktor penyelesaian konflik karena pegawai senang memberikan gambaran permasalahan di lingkungan kerja. Indikator keterikatan pegawai tertinggi yaitu pada dimensi pekerjaan dan lingkungan kerja karena pegawai memiliki antusias berkembang dalam berbagai kesempatan.

\section{Saran}

Beberapa saran yang dapat diberikan dan diharapkan dapat bermanfaat bagi Kantor Pusat OJK Jakarta dan penelitian selanjutnya yaitu dimana keterikatan pegawai Kantor Pusat OJK Jakarta sebaiknya ditingkatkan dengan memprioritaskan nilai budaya profesionalisme dan sinergi dengan mengadakan sharing knowledge departemen melalui pemanfaatan sarana learning center dan melaksanakan SOP review untuk meningkatkan sikap saling percaya antarpegawai. Sub-faktor penyelesaian konflik dalam kualitas kehidupan kerja yang dapat ditingkatkan yaitu proses penyampaian keluhan, sehingga pemimpin dapat mengembangkan praktik negosiasi dalam pengelolaan manajemen konflik. Dan untuk penelitian selanjutnya dapat dilakukan analisis pengaruh budaya organisasi dan kualitas kehidupan kerja terhadap keterikatan pegawai lintas generasi dengan menggunakan metode penarikan sampel sensus untuk mengetahui persepsi dan pengaruh variabel penelitian secara lebih luas di Kantor Pusat OJK Jakarta.

\section{REFERENSI}

Akbar, M. R. (2013). Pengaruh Budaya Organisasi terhadap Employee Engagement (Studi pada Karyawan PT Primatexco Indonesia di Batang). Journal of Social and Industrial Psychologi. 2(1), 10-18.

Avianti, D. A, \& Kartika, L. (2016). Analisis Quality of Work Life pada Generasi X dan Y Alumni Fakultas Ekonomi dan Manajemen IPB. Jurnal Riset Manajemen dan Bisnis, $2(2)$.

Cascio, W. F. (2003). Managing Human Resources: Productivity, Quality of Work Life, Profits. 7th Edition. New York (US): Mc. Graw-Hill Inc.

De Meuse, K,\&Mlodzik, K. (2009). A Scholarly Investigation of Generational Workforce Differences: Debunking the Myths. Los Angeles (US): Korn/Ferry International. 
Duffy, G. L., Laman, S. A., Mehta, P., Ramu, G., Scriabina, N.,\&Wagoner, K. (2012). Beyond The Basics Seven New Quality Tools Help Innovative, Communicate and Plan. Amerian Society for Quality (US): Quality Progress.

Fatimah, H,, Dharmawan, A. H., Sunarti, E, \& Affandi, M. J. (2015). Pengaruh Faktor Karakteristik Individu dan Budaya Organisasi terhadap Keterikatan Pegawai Generasi X dan Y. Jurnal Aplikasi Manajemen, 13(3).

Hadad, M. D. (2017). OJK Way Implementasi Perubahan Manajemen di OJK. Jakarta (ID): Grasindo.

HR in Asia. (2016). Top 5 best emloyers in Indonesia for 2016. Artikel.

Kartika, L. (2009). Analisis Kepuasan Kerja Karyawan melalui Faktor-Faktor Quality of Work Life pada PT Pertamina (Persero) Perkapalan. Tesis. Universitas Indonesia (ID).

Lockwood, N. (2007). Leveraging Employee Engagement for Competitive Advantage.Society For Human Resource Management Reseach.

Luntungan, I., Hubeis, A. V. S., Sunarti, E., \&Maulana, A. (2014). Strategi Pengelolaan Generasi Y di Industri Perbankan. Jurnal Manajemen Teknologi, 13(2).

Maarif, M. S, \& Kartika, L. (2014). Manajemen Pelatihan Upaya Mewujudkan Kinerja Unggul dan Pemahaman Employee Engagement. Bogor (ID): IPB Press.

Mangkunegara, A P. (2005). Perilaku dan Budaya Organisasi. Bandung (ID): PT Refika Aditama.

Muftah, H. A., \&Lafi, H. (2011). Impact of QWL On Employee Satisfaction Case of Oil and Gas Industry in Qatar. Journal Advances in Management and Applied Economics.

Mukundan, S., Mukundan, D, \& Sarawathyamma, K. P. (2013). A study on the conflict resolution styles of generation $Y$ students in Indian context.International Journal of Global Business, 6(1).

Murphy, S. A. (2007). Leading A Multigenerational Workforce. Washington, D.C (US): American Association of Retired Persons.

Octaviani, S, \& Fakhri, M. (2016). Pengaruh Budaya Organisasi terhadap Employee Engagement pada Fakultas Ekonomi dan Bisnis serta Fakultas Komunikasi dan Bisnis Universitas Telkom. Jurnal Valuta, 2(2).

Otoritas Jasa Keuangan. (2017). Employee opinion survey OJK. Jakarta (ID): Otoritas Jasa Keuangan.

Otoritas Jasa Keuangan. (2012). Peraturan Dewan Komisioner Otoritas Jasa Keuangan Nomor 01/15/PDK/ XII/2012 tentang Grading Jabatan di Otoritas Jasa Keuangan. Jakarta (ID).

Otoritas Jasa Keuangan. (2011). Undang-Undang No. 21 Tahun 2011 tentang Otoritas Jasa Keuangan. Jakarta (ID).

Pandey, A. (2017). Engaging Millennials in The Workplace Tips and Learning Strategies That Work. French (FR): Elearning Industry.

Robbins, S, \& Judge, T. (2012). Organizational Behavior. New York (US): Pearson Education.

Schaufeli, W. B, \& Bakker, A. B. (2004). Utrecht Work Engagement Scale (UWES) Preliminary Manual.

Susanto, A. B., Sujanto, F. X., Wijanarko, H., Susanto, P., Mertosono, S, \& Ismangil, W. (2008). A Strategic Management Approach Corporate Culture and Organization Culture. Jakarta (ID): The Jakarta Consulting Group.

Sutrisno, E. (2011). Budaya Organisasi. Jakarta (ID): Kencana Prenada Media Group.

Tahir, R. (2015). Faktor Kualitas Kehidupan Kerja dan Keterikatan Karyawan. Jurnal Manajemen Bisnis, 2(2). 
Uha, I. N. (2013). Budaya Organisasi Kepemimpinan dan Kinerja. Jakarta (ID): Prenadamedia Group. 